https://doi.org/10.48009/1_iis_2007_24-29

\title{
WEBLOGS: AN EXPLORATORY STUDY OF UNDERGRADUATE BEHAVIOR BY ACTIVITY AND GENDER
}

\author{
Carl J. Case, St. Bonaventure University, ccase@sbu.edu \\ Darwin L. King, St. Bonaventure University, dking@sbu.edu
}

\begin{abstract}
Weblogs (also known as blogs) are being increasingly used in the business world to communicate information from both the corporate and consumer perspectives. Little research, however, has been conducted to examine weblogging at the undergraduate level. This study, therefore, was conducted to empirically investigate student behavior and perceptions. Results suggest that blogging is not common among students, varies by type of blog and by gender, and is not similar to that of the general population. In addition, bloggers perceive information on blogs to be much more accurate than non-bloggers.
\end{abstract}

Keywords: Weblog, blog, undergraduates, empirical survey

\section{INTRODUCTION}

A blog (short for weblog) is a personal online journal that is frequently updated and intended for general public consumption [22]. Blogs are defined by their format: a series of entries posted to a single page in reverse-chronological order. Software such as Blogger allows an individual to develop a weblog within minutes [14].

In 2001, 90 million Americans participated in online groups [9]. By 2005, one-fifth of teens had blogs and $38 \%$ indicated reading other individual $=$ s blogs. One tenth of adults had blogs and one quarter read other $=\mathrm{s}$ online journals [10]. By 2006, a Scripps Survey Research Center survey of 1,010 adult US residents found nearly one-quarter of young adults read blogs at least one time per week, compared to $3 \%$ of individuals 65 or older [5]. Only one in eight adults, however, used blogs to get news and information. Eighty-eight percent indicated never using blogs to get news, 7\% read blogs four days a week or less, and $5 \%$ read them five days or more per week.

According to Technorati, a blog search engine, there were 57 million blogs worldwide in October 2006, a $185 \%$ increase from the 20 million blogs that were on the Internet 12 months earlier [23]. Moreover, the blogosphere is doubling in size every 200 days with 1.6 million new postings worldwide each day or about 19 postings every second. One estimate is that there are approximately 40,000 new weblogs each day [21]. In a summer 2006 survey, the Pew Internet and American Life Project found that just 8 percent of American Internet users keep blogs but 39 percent read them [16]. The most popular blogs on the Internet are MySinablog, which is a Chinese culture site, Engadget, a gadget guide, Boing Boing, which is a blog about geek culture, Gizmodo, a gadget blog, and Xu Jinglei, a Chinese culture blog [18].

Blogging is gaining acceptance in several arenas. The National Writing Project (NWP), for example, a federally funded program that serves more than 100,000 teachers, encourages the use of blogging to help students become successful writers and learners [1]. Blogging is encouraged to promote the integration of technology into writing instruction. Blogs are also growing in importance for artists and music marketers and may be becoming as important as traditional communication media, although there is little empirical research related to that type of marketing [3].

Businesses have also begun to embrace blogs. In 2006, 40 companies in the Fortune 500 had blogs [8]. Technology companies such as Amazon.com, Cisco Systems Inc., Oracle Corporation, and Sun Microsystems Inc. have been early adopters of blogs [12]. The Sun CEO publishes his blog in 10 languages to generate new customers and attract prospective employees. High profile bloggers include the CEO of Jupitermedia Corporation, IBM Rational=s chief scientist, and a VP of engineering at Disney ABC Cable Networks Group [17].

There is evidence that the influence of blogs on corporate reputation is increasing. Hotwire's Blog Impact Barometer 2006 research found that 25 million adults in Western Europe changed their minds about a company or its products after reading comments or reviews on a blog [4]. Thirty-four percent decided not to purchase a product after reading comments on a blog. Interestingly, the survey found that blogs are second only to newspapers as the 
most trusted source of information; $24 \%$ of respondents consider them a trusted source, behind newspaper articles (30\%), but ahead of TV advertising (17\%) and email marketing (14\%).

The use of blogs is not without challenges. One researcher believes that the increasing use of informal methods of sharing information such as blogs and self-publishing may result in a destabilizing impact on the current formal research process [6]. Today, the process of transferring information is through various formal channels - from book or journal publication to speeches at conferences or preprint reports of research.

A second challenge is that $9 \%$ of new blogs are reported as spam blogs, or splog [7]. Splog results when you run a blog search, click on the posting, and end up at a site advertising a product.

Another growing trend is for a company to create a fake weblog (flog) to promote its company and brands. PayPerPost landed \$3 million in funding for a business model built by paying bloggers to endorse products and operates a marketplace in which advertisers can find bloggers willing to endorse their products [21]. Wal-Mart, however, received negative publicity when it was discovered that a blog called "Wal-Marting Across America" was funded indirectly by Wal-Mart [8]. General Motors, on the other hand, posts its code of ethics which insists that bloggers tell the truth and not delete comments unless they are spam, off-topic, or defamatory.

Privacy and legal issues are also concerns. A Pew survey found $79 \%$ of teens agreed that individuals their own age are not careful enough when giving out personal information, such as posting cell phone numbers on their blogs [10]. Google employee Mark Jen speculated online about his employer's finances and Ellen Simonetti posted photographs of herself posing in a Delta Airlines uniform inside a company airplane. Both were fired [11]. In 2005, an affiliate of the Automobile Club of Southern California fired 27 employees after a co-worker complained about harassing and insulting comments the employees made on web postings [15]. In addition, the use of someone else $=\mathrm{s}$ material in a company blog could make the company liable for copyright infringement. Moreover, a company could be liable if the content is not true or contains negative comments about a competitor [19].

To help better understand blogs, Web mining and network analysis techniques have been recently utilized to analyze the content of blogs [2].
Researchers found that by employing a blog spider, information extraction, network analysis, and visualization, they could identify and analyze a selected set of anti-Blacks hate groups to discern demographic and topologic characteristics in the groups.

Researchers have also developed BlogPulse, an automated trend discovery system and portal for blogs [20]. The system utilizes machine learning, natural language processing, and sophisticated algorithms to examine turns of phrases that are occurring over time. Phrases are clustered together into blogbites to determine the most utilized words and phrases.

Furthermore, previous researchers have attempted to provide a theoretical understanding of why individuals blog [13]. Lee, for example, characterizes a blog as a good and a blogger as both a consumer and producer, in short, an active consumer. Blogs distinguish themselves from other forms of communication because blogs provide better personal care, more freedom of expression, more blogger autonomy and independency, and a more extensive chain of network possibilities. With these characteristics, Lee defines blogging as a noveltyseeking behavior.

Undergraduates represent the current consumers of blogs and will be the business bloggers of the future. It is important, therefore, to have a better understanding of their behavior to determine if blogging techniques, ethics, legal issues, and so on need to be introduced into the undergraduate education. As a result, this study was undertaken to gain insight into student behavior and perceptions.

\section{RESEARCH DESIGN}

This study employs a survey research design. The research was conducted at a private northeastern U.S. university. A Student Blog Usage survey instrument was developed and administered during the Fall 2006 semester to undergraduate students enrolled in a School of Business course. The sample had a 100\% response rate and included a variety of courses such as BIS-310 "Business Information Systems", BIS335 "System Analysis and Design", ACCT-201 "Introduction to Financial Accounting", ACCT-202 "Introduction to Managerial Accounting", and MSC413 "Business Policy.” A convenience sample of class sections was selected in order to maximize student participation. The class sections were conducted by a variety of faculty. 
The survey instrument was utilized to collect student demographic data and examine student behavior and perceptions regarding blogs. The survey requested that each student estimate the number of hours per week that he/she blogged, the quantity of various types of blogs that he/she read, and perceptions regarding blog accuracy. The survey was administered during the final week of the 15-week semester and all surveys were anonymous. Moreover, students were informed that results would have no effect on their semester grade.

\section{RESULTS}

A sample of 230 usable surveys was obtained. Sixtytwo percent of the respondents were male and 38\% were female. The response rate by academic class is distributed among Freshmen, Sophomore, Junior, and Senior classes. Eighteen percent of respondents were freshmen, $18 \%$ were sophomores, $24 \%$ were juniors, and $40 \%$ were seniors.

Blogging activity was examined to determine the duration of reading and writing activity per week (Table 1). Results illustrate that only three percent of students maintain a personal blog. These individuals indicate writing 1.4 hours per week in their blog. In terms of blog reading, $10 \%$ of respondents read personal blogs, six percent read educational blogs, and five percent read business blogs. Respondents indicated spending 2.1 hours, 2.1 hours, and 1.9 hours, respectively, reading the three types of blogs. Overall, $15 \%$ of respondents indicated either writing or reading blogs. The total reading and writing time was 3.2 hours per week per blogger.

\section{<Insert Table 1 here $>$}

Blog type and volume are depicted in Table 2 . Respondents read an average of 12.7 personal blogs in a given week. Only 1.9 educational blogs and 3.2 business blogs were read per week.

\section{<Insert Table 2 here $>$}

Data were next segmented by blogger versus nonblogger. Bloggers indicated that $39.4 \%$ of the information in personal blogs is accurate. Moreover, bloggers perceived $36.5 \%$ of information in educational blogs and $38.2 \%$ of information in business blogs are accurate. Non-bloggers, on the other hand, only believe that $2.6 \%$ of the information in personal blogs, $3.8 \%$ of the information in educational blogs, and $3.6 \%$ of the information in business blogs is accurate. In terms of accepting money for endorsing a product on a blog, $41 \%$ of bloggers and $9 \%$ of non-bloggers indicated a positive response.

\section{$<$ Insert Table 3 here $>$}

Finally, a t-test for equality of means was utilized to determine if blogging behavior varies among gender (Table 4). Gender means varied at the .005 significance level for reading educational blogs. In addition, only males reported reading business blogs. No variance was detected with regard to writing blogs and reading personal blogs.

\section{$<$ Insert Table 4 here $>$}

\section{CONCLUSIONS AND FUTURE RESEARCH}

Results suggest that blogging is not common among undergraduates. Only three percent of students write blogs each week. Moreover, only $10 \%$ read personal blogs, 6\% read educational blogs, and 5\% read business blogs. Overall, merely 15\% indicated any blogging behavior. In terms of duration, 1.4 hours per week was spent writing a blog. Only 2.1 hours was expended reading personal blogs, 2.1 hours was spent reading educational blogs, and 1.9 hours spent reading business blogs. In total, the average blogger spends a little more than three hours per week in blogging activities.

Findings also indicate a wide range in type of blog that are read. Nearly 13 different personal blogs were read each week. This is in sharp contrast to only 2 educational blogs and 3 business blogs read per week per blogger.

By examining accuracy perceptions, it appears that blogger and non-blogger behavior varies. Bloggers believe that nearly $40 \%$ of information in personal blogs, $37 \%$ of information in educational blogs, and $39 \%$ of information in business blogs is accurate. Non-bloggers, however, believe that between 3-4\% of any blogging information is accurate. This is in contrast to the Hotwire study that found $24 \%$ of respondents consider blogs to be a trusted source. Moreover, while $41 \%$ of bloggers would accept money to endorse a product on a blog, only $9 \%$ of non-bloggers would accept the offer.

Finally, duration of activity varies by gender. Females spend significantly more time reading educational blogs than males. In addition, only males reported reading business blogs.

There are several important implications as a result of these findings. One implication is that blogging is in 
its infancy with regard to undergraduate students. It is possible, however, that substitution communication technologies such as cell phones, instant messaging, text messaging, and electronic mail fulfill the student desire to be part of a group and enable one to communicate more quickly.

A second implication is that it is apparent that bloggers and non-bloggers are dramatically different. Bloggers believe that nearly $37-40 \%$ of information in blogs is accurate and $41 \%$ would accept money to endorse a product on a blog. Non-bloggers, however, believe that only between 3-4\% of any blogging information is accurate and only $9 \%$ would accept money to endorse a product.

A third implication is that gender is a factor with regard to blogging behavior. Females spend more time reading educational blogs and only males read business blogs. Further research is needed to determine why there is such an extreme variance in behavior.

A fourth implication is that undergraduate behavior is considerably different than behavior reported in previous studies. Only 3\% of students reported having their own blog but a 2005 survey found onetenth of adults had a blog and Pew found that $8 \%$ of American Internet users keep blogs. In addition, this survey found that only $15 \%$ of students either read or write blogs but a Scripps survey concluded that onequarter of young adults read blogs weekly and Pew found that $39 \%$ of American Internet users read blogs.

A final implication is that organizations such as PayPerPost may be able to utilize undergraduates to endorse products. Forty-one percent of bloggers indicated that they would accept money to endorse a product on a blog. It is uncertain, however, if student opinions would be effective in increasing a product's sales.

One limitation of this study is a function of sample size. A larger sample size, use of additional universities, and more equal distribution of respondents by academic class and gender would increase the robustness of results. Another limitation relates to the self-reported nature of the survey. Students are using recall thus recency effects may occur. In addition, the Hawthorne Effect may be a factor.

Future research should be directed at examining the content of blogs and factors such as academic class and gender influences upon behavior. Findings from such research would be useful in better explaining the current state of blogging. Overall, the current results and future research are important pedagogical findings that will assist information system faculty is improving student undergraduate education and technological behavior.

\section{REFERENCES}

1. Brown, J. (2007). On Target. TH E Journal, 34(1), 18-24.

2. Chau, M., \& Xu, J. (2007). Mining communities and their relationships in blogs: A study of online hate groups. International Journal of Human-Computer Studies, 65(1), 57-70.

3. Dickey, I. J., Rolston, C.P., \& Lewis, W. F. (2006). An Exploratory Study of Leveraging Search Engine Marketing, Weblogs, and MCommerce in Innovative Marketing Communication Programs in the Music Industry. Proceedings of the American Society of Business and Behavioral Sciences, 13(1), Las Vegas, NV, February 23-26, 367-374.

4. Gray, R. (2006). Wake up to digital danger. Marketing, 12/6/2006, 38.

5. Hargrove, T. \& Stempel III, G. H. (2006). Survey Finds Few American Adults Use Blogs to Get News. The Times Herald, September 13, B-4.

6. Herther, N. K.. (2005). Information retrieval. Blackwell Encyclopedic Dictionary of Management Information Systems, 1-171.

7. Heun, C. (2006) Invasion of the Splogs. Informationweek.com, 1089, 63-64.

8. Hoover, J. N. (2006) Revenge of the Suits: Companies Show How to Blog.

Informationweek.com, 1111, 38.

9. Horrigan, J. (2002). Online Communities: Networks That Nuture Long-Distance Relationships and Local Ties. Pew Internet American Life Project. http://www.pewinternet.org/reports/toc.asp?Rep ort $=47$

10. Irvine, M. (2005). Bloggers Learn the Price of Telling Too Much. The Times Herald, July 14, B-12.

11. Jesdanun, A. (2005). Getting Fired for Blogging. The Times Herald, March 14, A-9.

12. Konrad, R. (2006). Sun CEO at Communications Vanguard, Among Few Speaking to Public From Blog. The Times Herald, September 17, B-1.

13. Lee, S. C. (2006). An Active Consumer Theory Perspective on Blogs. Issues in Information Systems, VII(2), 269-274.

14. Lewis, W. F. \& Dickey, I. J. (2006). The 
Evolution of Internet Weblogs: History, Current Trends, and Projections for Advertising on Weblogs. Proceedings of the American Society of Business and Behavioral Sciences, 13(1), Las Vegas, NV, February 23-26, 1183-1190.

15. McGee, M. K. (2005) HR Struggles With Employee Web Posts. Informationweek.com, 1052, 28.

16. Moore, N. C. (2007). Bloggers Press for Power. State Legislatures, 33(1), 22-24.

17. Nash, J. (2005) Look Who=s Blogging. Informationweek.com, 1029, 47-52.

18. Pattillo, G. (2007). Fast Facts. College \&
Research Libraries News, 68(1), 64.

19. Schwartz, E. (2005). Bloggers and the Law. Inforworld.com, 27(19), 10.

20. Scott, D. M. (2005). Faces of Econtent. EContent, 28(1/2), 30.

21. Wagner, M. (2006) Can Bloggers Be Bought? Informationweek.com, 1110, 23.

22. whatis.com (2007). What is a blog? http://searchvb.techtarget.com/sDefinition/0,290 660,sid8_gci214616,00.html

23. ---- (2007). Up Front, Year Over Year, Eclectic Indicators. BusinessWeek, 4016, 12.

TABLES AND FIGURES

Table 1. Blogging Activity

\begin{tabular}{||l|r|r||}
\hline \multicolumn{1}{|c|}{ Activity } & $\begin{array}{c}\text { \% of } \\
\text { Respondents }\end{array}$ & $\begin{array}{c}\text { Hrs/week per } \\
\text { Respondent }\end{array}$ \\
\hline \hline Writing my own blog & $3 \%$ & 1.4 \\
\hline Reading personal blogs & $10 \%$ & 2.1 \\
\hline Reading educational blogs & $6 \%$ & 2.1 \\
\hline Reading business blogs & $5 \%$ & 1.9 \\
\hline \hline Either reading or writing blogs (unduplicated) & $15 \%$ & 3.2 \\
\hline
\end{tabular}

Table 2. Blog Type and Volume

\begin{tabular}{||c|r||}
\hline Type of Blog & $\begin{array}{r}\text { Average per } \\
\text { Respondent }\end{array}$ \\
\hline \hline \# of different personal blogs read in a given week & 12.7 \\
\hline \# of different educational blogs read in a given week & 1.9 \\
\hline \# of different business blogs read in a given week & 3.2 \\
\hline
\end{tabular}

Table 3. Blogger Versus Non-Blogger Perceptions

\begin{tabular}{||c|r|r||}
\hline \multicolumn{1}{|c|}{ Activity } & Bloggers & Non-Bloggers \\
\hline \hline \% of information in personal blogs that is accurate & $39.4 \%$ & $2.6 \%$ \\
\hline$\%$ of information in educational blogs that is accurate & $36.5 \%$ & $3.8 \%$ \\
\hline \% of information in business blogs that is accurate & $38.2 \%$ & $3.6 \%$ \\
\hline I would accept money to endorse a product on a blog & $41.1 \%$ & $9.1 \%$ \\
\hline
\end{tabular}


Table 4. Blogging Activity by Gender (t-test for Equality of Means)

\begin{tabular}{||l|r|r||}
\hline \multicolumn{1}{|c|}{ Activity } & Male Mean & Female Mean \\
\hline \hline Writing my own blog & 1.8 & 1.0 \\
\hline Reading personal blogs & 2.2 & 2.1 \\
\hline Reading educational blogs & 1.6 & $4.0^{*}$ \\
\hline Reading business blogs & 1.9 & \\
\hline
\end{tabular}

* significant at .005 level (2-tailed) 